\title{
Penetrasi Google Classroom pada Siswa Sekolah Menengah Kejuruan pada Pembelajaran Daring di Era Pandemi
}

\author{
Sarjono ${ }^{1^{*}}$ \\ ${ }^{1}$ SMK Negeri 4 Pangkalpinang, Provinsi Bangka Belitung, Indonesia
}

${ }^{*}$ Corresponding Author. E-mail: ${ }^{1}$ sarjonopkppbb@gmail.com

\begin{tabular}{|l|l|l|}
\hline Receive: 13/05/2021 & Accepted: 23/08/2021 & Published: 01/10/2021
\end{tabular}

\begin{abstract}
Abstrak
Dunia pendidikan sempat mengalami vacum ketika pandemi Corona Virus Disease (Covid-19) melanda Indonesia pada awal tahun 2020. SMK Negeri 4 Pangkalpinang Provinsi Bangka Belitung menerapkan beberapa aplikasi dalam pelaksanaan proses pembelajaran diantaranya Google Classroom. Di awal penerapan Google Classroom sempat membuat guru dan siswa ragu karena dianggap baru. Penelitian ini bertujuan untuk mengetahui penetrasi dan efektivitas penggunaan aplikasi Google Classroom dalam proses pembelajaran di SMK Negeri 4 Pangkalpinang. Penelitian didasarkan pada pengalaman siswa pada awal pembelajaran daring (awal 2020) dan setelah berlangsung selama lebih dari satu tahun (awal 2021). Pada penelitian ini dilakukan evalusi terhadap pelaksanaan pembelajaran daring menggunakan Google Classroom. Hal yang diuraikan adalah pengamatan terhadap keterlibatan siswa dan efektivitas pembelajaran secara kualitatif, berbagai permasalahan dan upaya-upaya solusi dalam perjalanan pembelajaran daring sehingga lebih efektif. Pengalaman siswa secara kuantitatif didapatkan melalui kuesioner yang dibagikan kepada keseluruhan populasi 30 siswa kelas XINKN1 SMKN 4 Pangkalpinang. Kuesioner berisi pertanyaan tentang refleksi pengalaman pada Maret 2020 (awal pembelajaran daring) dan pada Juli 2021 (setelah lebih dari satu tahun pembelajaran daring). Hasil penelitian menunjukkan pembelajaran daring melalui media Google Classroom efektif untuk mengatasi batas waktu, ruang, dan jarak. Siswa antusias untuk mengikuti proses pembelajaran. Pembelajaran daring dari awal pandemi hingga sekarang secara kualitatif telah mendapatkan efektivitas. Google Classroom telah menjadi pengganti pertemuan di kelas secara luring, dengan segala kelebihan dan kekurangannya. Secara kuantitatif yang dirasakan oleh siswa telah mendapatkan respon positif dengan penetrasi dan lompatan dalam lima hal, yaitu keberadaan, pemakaian, kemampuan menggunakan, kenyamanan, dan efektivitas penggunaan Google Classroom.
\end{abstract}

Kata Kunci: penetrasi, Google Classroom, daring, siswa, pandemi, Covid-19

\section{Penetration of Google Classroom for Vocational High School Student on Online Learning in Pandemic Era}

\begin{abstract}
The world of education experienced a vacuum when the Corona Virus Disease (Covid-19) pandemic hit Indonesia in early 2020. SMK Negeri 4 Pangkalpinang, Bangka Belitung Province implemented several applications in the learning process including Google Classroom. At the beginning of the implementation of Google Classroom, teachers and students had doubts because it was considered new. This study aims to determine the penetration and effectiveness of Google Classroom application in the learning process at SMK Negeri 4 Pangkalpinang. Research is based on student experiences at the start of online learning (early 2020) and after more than one year (early 2021). In this study, an evaluation of the implementation of online learning using Google Classroom was carried out which are the observation of student involvement and the effectiveness of qualitative learning, various problems and efforts to solve the online learning journey so that it is more effective. Students' experiences were quantitatively obtained through questionnaires distributed to a total population of 30 students of class XINKN1 at SMKN 4 Pangkalpinang. The questionnaire contains questions about reflection on experiences in March 2020 (beginning of online learning) and in July 2021 (after more than one year of online learning). The results of the study show that online learning through Google Classroom is effective in overcoming the limitations of time, space, and distance. Students are enthusiastic to follow the learning process. Online learning from the beginning of the pandemic until now has qualitatively gained effectiveness. Google Classroom has become a substitute for offline classroom meetings, with all its advantages and disadvantages. Quantitatively what students feel has received a positive response with penetration and leaps in five things, namely presence, usage, ability to use, comfort, and effectiveness of using Google Classroom.
\end{abstract}

Keywords: penetration, Google Classroom, online, student, pandemic, Covid-19 


\section{Pendahuluan}

Dunia pendidikan sempat mengalami vacum ketika pandemi Corona Virus Disease (Covid-19) menyebar secara merata di seluruh wilayah Indonesia pada awal tahun 2020. Semua proses pembelajaran pada semua jenjang menjadi terhenti sehingga guru dan siswa beraktivitas di rumah saja. Aji dkk (2020) mengatakan bahwa virus corona telah mengganggu tatanan kehidupan di seluruh dunia tanpa kecuali di Indonesia. Salah satu akibat menyebarnya wabah virus corona adalah diliburkannya sekolah mulai dari jenjang pendidikan usia dini sampai dengan perguruan tinggi dengan maksud untuk menghentikan penyebaran virus corona antara satu orang dengan orang yang lainnya.

Menteri Pendidikan dan Kebudayaan Republik Indonesia melalui Surat Edaran No. 04 tahun 2020 menetapkan Pelaksanaan Kebijakan Pendidikan dalam Masa Darurat Penyebaran Covid-19 yang salah satu isinya adalah proses pembelajaran dilakukan dari rumah saja atau bagi guru berlaku Work from Home (WFH). Proses pembelajaran dalam jaringan (daring) atau online tersebut mensyaratkan guru harus menggunakan teknologi yang dapat mendukung proses pembelajaran. Menurut Ngafifi (2014), teknologi digunakan karena manusia makhluk pintar yang selalu berpikir dan menginginkan lebih baik dalam menjalani kehidupannya maupun dalam menyelesaikan permasalahan.

Direktur Jenderal Guru dan Tenaga Kependidikan Kemendikud mengatakan bahwa teknologi digunakan sebagai alat untuk memudahkan guru dalam menciptakan pembelajaran yang menarik dan efektif. Efektif atau tidaknya dalam pembelajaran tergantung kepada guru dalam merancang dan merencanakan pembelajaran. Dalam Peraturan Pemerintah Nomor 32 tahun 2013 tentang perubahan atas Nomor 19 tahun 2005 tentang standar nasional pendidikan dikatakan bahwa proses pembelajaran pada satuan pendidikan diselenggarakan secara interaktif, inspiratif, menyenangkan, menantang, dan memotivasi peserta didik untuk berpartisipasi aktif, serta memberikan ruang yang cukup bagi prakarsa, kreativitas, dan kemandirian sesuai dengan bakat, minat, dan perkembangan fisik serta psikologis peserta didik.

Teknologi dalam proses pembelajaran adalah alat atau media yang berisi aplikasi yang digunakan guru untuk mendukung dan memfasilitasi proses pembelajaran secara daring (dalam jaringan) maupun luring (luar jaringan). Aplikasi yang dimaksud adalah aplikasi yang dapat diakses oleh android atau komputer serta personal komputer. Hasil penelitian Mulyani (2018) dapat menyatakan bahwa penerapan aplikasi android dapat meningkatkan hasil pembelajaran siswa dan memberikan dampak yang baik bagi peningkatan kualitas pembelajaran siswa.

Pada awal pelaksanaan pembelajaran daring, seperti disampaikan pada hasil penelitian Firdaus (2018), Munarah, Makarina (2019), dan Sartika, Sahidillah dan Prarasto (2019), diketahui bahwa WhatsApp digunakan sebagai media pembelajaran dan alat komunikasi melalui pesan atau voice yang dapat digunakan oleh guru dan siswa dalam memberikan dan mengumpulkan tugas, mengontrol, dan mengecek kehadiran siswa. Perjalanan selanjutnya muncul aplikasi yang bersifat teleconference dengan mempertemukan guru dan siswa secara tatap muka walaupun terpisah jarak. Salah satu aplikasi yang dimaksud adalah Zoom yang dapat membantu guru dan siswa dalam proses belajar karena fitur yang disediakan lengkap untuk berinteraksi. Guru bisa berdiskusi langsung menggunakan fitur video, menampilkan materi secara bersamaan, dan memantau kehadiran bahkan sikap siswa selama proses pembelajaran. Jika guru mampu merancang pembelajaran secara menarik maka proses pembelajaran akan menarik dan menyenangkan.

Proses pembelajaran secara daring pada awal mulanya sempat membingungkan bagi guru apalagi bagi siswa. Guru adalah penggerak dan pelaksana di dunia pendidikan 
sehingga penguasaan terhadap aplikasi pembelajaran daring bersifat wajib. Untuk memudahkan guru dalam mengakses aplikasi tersebut, maka sekolah perlu melatih guru dalam mengenalkan dan menggunakan aplikasi sehingga dapat memilih dan menerapkan salah satu jenis aplikasi kedalam proses pembelajaran secara daring sesuai dengan kebutuhan siswa. Dalam penelitiannya, Baharuddin dan Rabial (2017) dan Jayadipura (2018) mengatakan bahwa pelatihan berfungsi untuk pengembangan profesionalisme guru terutama dalam meningkatkan kemampuan dalam menguasai informasi atau teknologi baru yang berguna untuk mendesain ataupun menerapkan pembelajaran.

Cara lain dalam meningkatkan kompetensi guru terhadap aplikasi baru tersebut selama masa pandemi Covid-19 adalah melalui webinar. Menurut Verma dan Annop (2010), webinar berasal dari kata web dan seminar yang berarti seminar dilakukan secara online atau melalui internet. Dengan demikian, webinar adalah seminar yang dilakukan dalam jaringan jarak jauh yang bertujuan untuk mendapatkan pengetahuan dan informasi baru.

Proses pembelajaran dari rumah atau Work from Home (WFH) mengharuskan guru menggunakan berbagai macam aplikasi dalam menyampaikan pengetahuan atau materi pembelajarannya kepada siswa. Dalam penelitiannya, Rasyid (2008) mengatakan bahwa guru harus kreatif, aktif, dan melakukan terobosan ketika merencanakan pembelajaran (merancang, memilih materi, metode, media, alat, bahan, strategi) maupun dalam penyampaian ilmu atau informasi kepada siswa, sehingga siswa merasa tertantang untuk selalu belajar.

Guru yang profesional harus memiliki skill untuk menguasai teknologi terbaru termasuk aplikasi yang digunakan dalam pembelajaran daring. Aplikasi yang digunakan guru harus dimiliki tentu juga oleh siswa. Dalam proses pembelajaran, guru harus bekerjasama dengan wali kelas, guru Bimbingan Konseling, dan orang tua dari siswa sehingga tidak terjadi komunikasi satu arah terutama dalam menggunakan aplikasi yang berhubungan dengan dunia maya. Muthmainnah, Riche, dan Cepi (2019) menyatakan bahwa dunia maya atau virtual classroom adalah pembelajaran yang dilakukan secara daring menggunakan paket data atau kuota internet dengan aplikasi tertentu sesuai dengan kebutuhan dan instruksi yang diberikan sehingga terwujud interaksi antara instruktur dan bimbingannya.

Jenis-jenis aplikasi yang dapat digunakan dalam proses pembelajaran diantaranya Zoom, Google Meet, Webex, Edmodo, Microsoft Teams, Instagram, WhatsApp, Google Form, dan Cloud. Hasil penelitian Zhafira, Yenni, dan Chairiyaton (2020) ditemukan bahwa siswa yang menggunakan aplikasi membuat siswa menjadi lebih aktif dalam mencari sumber-sumber belajar dan informasi baru. Hal ini menandakan bahwa aplikasi yang sesuai dengan keadaan siswa akan membawa dampak positif dalam proses pembelajaran.

Aplikasi Google Classroom terjadi salah satu aplikasi yang booming selama pandemi Covid-19. Menurut Brock (2015), Google Classroom memberikan beberapa manfaat seperti kelas dapat disiapkan dengan mudah, guru dapat menyiapkan kelas, dan mengundang siswa sehingga didalam aliran kelas dapat berbagi informasi seperti kehadiran, tugas, pengumuman, dan pertanyaan. Pratiwi (2020) dalam penelitiannya mengatakan bahwa Covid-19 telah merubah dunia pendidikan dasar maupun perguruan tinggi untuk melakukan pembelajaran secara virtual dan salah satu aplikasi yang digunakan adalah Google Classroom.

Guru profesional seperti yang tertuang dalam Undang-Undang Republik Indonesia Nomor 14 Tahun 2005 harus mengerahkan segenap kemampuan untuk membuat siswa menjadi manusia yang memiliki pengetahuan, 
berkompeten, berkarakter, dan mampu bersaing di dunia internasional. Dalam penelitian Wardani (2012), Muhlison (2014), dan Hanafi (2017) disebutkan bahwa guru adalah profesional yang mempunyai tugas mencerdaskan dan meningkatkan sumber daya manusia dari segi moral maupun spritual.

Dalam melaksanakan tugas, guru harus mampu beradaptasi dan berinovasi dalam menguasai teknologi informasi sesuai dengan kondisi saat ini. Begitu pula penerapan teknologi dalam proses pembelajaran, guru harus mampu menguasai dan menggunakan Google Classroom sebagai alat untuk berinteraksi atau berkomunikasi dengan siswa dalam menyampaikan informasi, ilmu atau bahkan materi pembelajaran yang dapat disaksikan secara langsung oleh siswa. Meskipun ada jarak yang memisahkan antara guru dan siswa, proses pembelajaran daring seperti ini bisa terlaksana dengan baik apabila didukung oleh kuota, sinyal, jenis handphone/personal computer, dan bahkan kemampuan ekonomi.

Setelah melakukan interaksi dengan siswa melalui aplikasi Google Classroom, banyak kelebihan-kelebihan yang dapat diambil, antara lain guru dapat berinteraksi secara langsung dengan siswa meskipun hanya di dunia maya. Guru dapat melihat kehadiran dan keikutsertaan siswa dalam proses pembelajarann. Guru dapat tanya jawab langsung dengan siswa melalui fitur yang disediakan, mudah mengelola tugas yang diberikan, guru dan siswa tidak perlu berada dalam satu ruangan untuk mengikuti proses pembelajaran.

Google Classroom adalah serambi pembelajaran campuran yang diperuntukkan bagi setiap ruang lingkup pendidikan yang dimaksudkan untuk menemukan jalan keluar atas kesulitan dalam membuat, membagikan, dan mengelompokkan setiap penugasan tanpa kertas. Google Classroom dianggap sebagai salah satu platform terbaik untuk meningkatkan alur kerja guru. Google Classroom menyedikan satu set fitur yang menjadikan tools ideal untuk digunakan bersama sisiwa. Google Classroom dapat membantu guru dalam menghemat waktu, mengajar kelas tetap teratur, dan dapat meningkatkan komunikasi dengan siswa. Aplikasi Google Classroom tersedia untuk semua orang dengan google apps for education, rangkaian tools produktivitas gratis termasuk gmail, drive, dan dokumen.

Penggunaan Google Classroom tidak perlu melakukan proses instalasi yang rumit. Setelah administrator memiliki account google yang dilengkapi dengan google apps for education untuk sekolah maka pengajar dan pelajar bisa menggunakan aplikasi Google Classroom dengan akun email google masingmasing. Pengajar membuat kelas baru di Google Classroom kemudian mengundang pelajar untuk bergabung dengan menyebarkan kode yang didapatkan ketika pendaftaran kelas baru. Karena terintegrasi dengan akun email google, penyebaran kode ini dapat dilakukan dengan mudah secara online maupun offline.

Model pembelajaran yang semakin kompleks dalam pelaksanaan proses pembelajaran yang berbasis online mendorong pendidik untuk memberikan model pembelajaran yang lebih menarik, berbeda dengan biasanya agar tujuan dari pembelajaran yang dilakukan dapat tercapai.

\section{Metode}

SMK Negeri 4 Pangkalpinang yang merupakan tempat mengajar penulis mempunyai peran penting dalam mempersiapkan Sumber Daya Manusia (SDM) yang unggul dan mandiri. Alumni/lulusan SMK Negeri 4 Pangkalpinang diharapkan memiliki kompetensi keahlian yang sesuai dengan bidangnya. Saat ini terdapat lima kompetensi keahlian yang ada di SMK Negeri 4 Pangkalpinang, yaitu Nautika Kapal Niaga (NKN), Teknik Nautika Niaga (TKN), Nautika Kapal Penangkap Ikan (NKPi), Agribisnis Perikanan Air Tawar (APAT), dan Agribisnis Pengolahan Hasil Perikanan (APHPi). Dengan 
adanya lima kompetensi keahlian tersebut diharapkan alumni/lulusan dari SMK Negeri 4 Pangkalpinang nantinya lebih mempermudah dalam mengarahkan langkah pendidkan tinggi yang hendak ditempuh. Selain itu juga, dengan keahlian yang dimilikinya, lulusan SMK Negeri 4 Pangkalpinang diharapkan juga agar memiliki sikap mandiri karena siap untuk bekerja dan membuka usaha sendiri sesuai dengan kompetensi keahlian yang dimilikinya.

Melihat kondisi pandemi Covid-19 yang berlangsung dengan belum diketahui waktu berakhirnya maka SMK Negeri 4 Pangkalpinang menerapkan beberapa aplikasi dalam pelaksanaan proses pembelajaran, diantaranya Zoom, Cloud, Google Classroom, WhatsApp, dan Google Meet.

Di awal penerapan penggunaan dari aplikasi Google Classroom sempat membuat guru ragu karena kemunculannya masih dianggap baru. Kerisauan dan kecemasan guru ini hilang ketika pihak sekolah berinisiatif melakukan workshop atau In House Trainning yang sangat membantu guru dalam mempraktekkan ilmu barunya sehingga mampu mengaplikasikan dalam bentuk proses belajar daring. Pemanfaatan aplikasi Google Classroom diharapkan dapat membuat proses pembelajaran daring menjadi lebih efektif.

Tujuan penulisan makalah ini adalah untuk mengetahui apakah dengan menggunakan aplikasi Google Classroom dalam proses pembelajaran di SMK Negeri 4 Pangkalpinang efektif atau tidak. Penelitian didadarkan pada pengalaman siswa pada awal pembelajaran daring (Maret 2020) dan setelah berlangsung selama satu tahun (Juli 2021).

Makalah ini diharapkan dapat dijadikan sebagai gambaran bagi sekolah terutama kepala sekolah dan pendidik untuk mempertimbangkan media pembelajaran yang tepat dalam proses pembelajaran daring. Di sisi lain, bagi siswa diharapkan agar selalu mengikuti perkembangan dan penguasaan teknologi sehingga dapat mengikuti pembelajaran dengan lancar selama masa pandemi. Secara praktis, makalah ini dapat dijadikan kontribusi bagi guru supaya tidak takut terhadap perkembangan teknologi akan tetapi harus sadar bahwa proses pembelajaran sangat memerlukan teknologi apalagi pada masa pandemi.

Aplikasi Google Classroom dipilih sebagai salah satu media untuk melakukan proses belajar mengajar secara daring di SMK Negeri 4 Pangkalpinang yang bertujuan supaya siswa tetap belajar. Semua guru di SMK Negeri 4 Pangkalpinang wajib menggunakan aplikasi Google Classroom yang booming selama pandemi Covid-19. Menurut Brock (2015), Google Classroom memberikan beberapa manfaat seperti kelas dapat disiapkan dengan mudah, guru dapat menyiapkan kelas dan mengundang siswa. Kemudian di dalam aliran kelas dapat berbagi informasi seperti kehadiran, tugas, pengumuman dan pertanyaan dalam proses pembelajaran disamping menggunakan aplikasi lain seperti WhatsApp, Instagram, dan sebagainya. Terjadi atau tidaknya interaksi antara guru dan siswa dalam pembelajaran tergantung guru dalam menyiapkan dan merencanakan pelaksanaan pembelajaran mulai dari kesiapan materi, media, alat, metode, pendekatan, strategi, dan bahkan kesiapan penyampaian materi itu sendiri. Persiapan yang matang akan membuat presentasi yang menarik dan menyenangkan sehingga terwujud proses pembelajaran yang efektif. Untuk menghindari terjadinya tumpang tindih antara satu kelas dengan kelas yang lain dalam proses pembelajaran daring, dibuat jadwal khusus sedemikian rupa sehingga efektif untuk semua warga kelas.

Proses pembelajaran mengacu pada tujuan yang diharapkan sehingga penggunaan model pembelajaran sangat membantu memperlancar tujuan pembelajaran. Makalah ini membahas penerapan model pembelajaran jarak jauh melalui media Google Classroom dalam proses pembelajaran dan kelebihan dan kekurangan dari model pembelajaran jarak jauh.

Langkah-langkah yang harus diikuti dalam menggunakan Google Classroom dalam 
proses pembelajaran jarak jauh yang telah dilakukan penulis, secara detail sama dengan apa yang telah diuraikan oleh Ginanjar (2016), diantaranya masuk aplikasi browser pada komputer desktop, masuk ke Google Classroom, login, masuk ke beranda, pendaftaran (gabung) kelas, daftar tugas, berbagi pesan atau memberi komentar, melihat nama teman, melakukan komunikasi, mengerjakan tugas, mengunggah atau menambahkan file, membatalkan pengumpulan tugas, pengiriman ulang tugas, dan notifikasi melalui email di smartphone.

Setelah pembelajar mengetahui langkahlangkah penggunaan media Google Classroom maka pengajar dapat memberikan tugas melalui media tersebut serta memberikan deadline mengenai tugas dan materi yang akan diberikannya. Pengajar memberikan rentang waktu selama satu minggu untuk para pembelajar mengeksplorasi materi dan mengerjakan tugas. Namun, pengajar tetap melakukan sesi tatap muka di kelas karena kelas virtual belum sepenuhnya dapat menggantikan kelas konvensional. Selanjutnya setelah penjelasan yang telah diberikan sebelumnya maka perlu diketahui kekurangan dan kelebihan yang terdapat dalam media tersebut.

Pada penelitian ini dilakukan evalusi terhadap pelaksanaan pembelajaran daring menggunakan Google Classroom. Penelitian menguraikan tentang pengalaman yang dialami penulis selama lebih dari satu tahun dalam pembelajaran daring pada SMK Negeri 4 Pangkalpinang Provinsi Bangka Belitung. Hal yang diuraikan adalah pengamatan terhadap keterlibatan siswa dan efektivitas pembelajaran secara kualitatif, berbagai permasalahan dan upaya-upaya solusi dalam perjalanan pembelajaran daring sehingga lebih efektif.

Pengalaman siswa secara kuantitatif didapatkan melalui kuesioner yang dibagikan kepada keseluruhan populasi 30 siswa kelas XINKN1 SMKN 4 Pangkalpinang. Kuesioner berisi pertanyaan tentang refleksi pengalaman pada Maret 2020 (awal pembelajaran daring) dan pada Juli 2021 (setelah lebih dari satu tahun pembelajaran daring). Refleksi yang digali adalah keberadaan, pemakaian, kemampuan menggunakan, kenyamanan, dan efektivitas penggunaan Google Classroom dalam pembelajaran daring.

\section{Hasil dan Pembahasan}

Penerapan model pembelajaran jarak jauh melalui media Google Classroom efektif untuk mengatasi batas waktu, ruang, dan jarak. Pembelajar yang tidak memiliki waktu luang dapat belajar secara mandiri dan mengumpulkan tugas layaknya di ruang kelas. Meskipun terdapat beberapa kendala saat seperti fasilitas internet atau komputer yang harus memadai, namun dengan tersedianya Google Classroom maka pembelajaran jarak jauh dapat diterapkan dengan efektif.

Selama proses pembelajaran menggunakan Google Classroom, siswa sangat antusias untuk mengikuti proses pembelajaran. Semua memperhatikan, menyimak, dan juga ikut berpartisipasi dalam proses pembelajaran. Hambatan yang utama adalah biaya yang digunakan untuk aplikasi ini termasuk mahal karena aplikasi ini menghabiskan banyak kuota. Masalah lain juga muncul ketika proses pembelajaran berlangsung adalah jaringan atau sinyal tibatiba tidak bagus dan bahkan sering membuat aplikasi log out sendiri, sementara untuk bergabung kembali perlu waktu yang menyebabkan siswa ketinggalan materi. Bagi siswa yang tinggal di desa tidak bisa mengakses internet karena belum tersediannya jaringan yang memadai. Kendala lain yang juga ditemukan masih banyak siswa yang kurang mampu, jangankan untuk beli pulsa, handphone yang digunakan tidak memungkinkan untuk aplikasi Google Classroom. Dengan kendala seperti ini pihak sekolah harus memikirkan solusi sehingga semua siswa mendapat kesempatan yang sama dalam proses belajar mengajar. 
Upaya dan harapan sekolah, siswa, dan orang tua dalam proses pembelajaran berdasar keterbatasan yang dialami siswa terhadap penggunaan aplikasi Google Classroom, pihak sekolah berinisiatif mendata siswa yang tidak mampu serta membantu untuk mempunyai kesempatan mengikuti proses pembelajaran. Bantuan yang diberikan berupa kuota atau kartu perdana sehingga siswa bisa mengakses pembelajaran dengan aplikasi Google Classroom. Hal ini juga didukung oleh Menteri Pendidikan dan Kebudayaan (2020) yang mengatakan bahwa dana Bantuan Operasional sekolah (BOS) boleh digunakan untuk membantu siswa dalam pembelian kuota internet untuk pembelajaran daring. Cara lain adalah mengirimkan materi dan tugas melalui aplikasi yang bisa diakses oleh siswa seperti WhatsApp dan Google Classroom.

Bantuan pihak sekolah kepada siswa diharapkan dapat semaksimal mungkin untuk menggunakan dan mengakses semua aplikasi terkait dengan proses pembelajaran. Dengan demikian semua siswa mendapat kesempatan yang sama dalam proses pembelajaran. Hal ini juga tertuang dalam Undang-Undang Sistem Pendidikan Nasional Bab IV tentang Hak dan Kewajiban Warga Negara, Orang Tua, Masyarakat, dan Pemerintah bagian kesatu Hak dan Kewajiban Negara Pasal 5 ayat 1 yang berbunyi setiap warga negara mempunyai hak yang sama untuk memperoleh pendidikan yang bermutu.

Keterlibatan dalam mengontrol anak dalam proses belajar dalam mendukung pembelajaran jarak jauh ini, orang tua diharapkan tetap mendampingi putra-putrinya dalam proses belajar sehingga anak-anak tetap termotivasi untuk senantiasa belajar. Keterlibatan orang tua mempengaruhi psikologi dan perkembangan anak dalam membentuk pola pikir. Belajar dari rumah bukan berarti anak tidak didampingi akan tetapi anak harus dikontrol terutama terhadap perkembangan kognitifnya. Jangan sampai anak menjadi pemalas dan tidak mau berkarya sehingga orang tua harus membantu dan mendampingi anak-anak, memberi pengertian bahwa belajar berlangsung seumur hidup baik itu bertatap muka langsung dengan guru maupun tidak. Dengan demikian anak tidak lalai terhadap kewajiban sebagai siswa terutama mengerjakan tugas yang diberikan guru.

Cahyati dan Kesumah (2020) mengatakan bahwa orang tua memegang peran sangat vital dalam masa pandemi Covid19 ini terutama dalam memberikan pendidikan yang bersifat formal seperti tugas yang diberikan oleh guru maupun tentang pandemi Covid-19 itu sendiri, dengan demikian anak dapat memahami apa yang boleh dan tidak boleh dilakukan selama berada di rumah. Hal ini juga disampaikan oleh Winingsih (2020) yang mengatakan bahwa orang tua memiliki peran sebagai guru, yaitu mendampingi, memfasilitasi, memotivasi, dan mengarahkan anaknya dalam belajar maupun dalam mengembangkan bakat dan interest-nya.

Terwujudnya pendidikan karakter tetap menjadi tujuan utama walaupun pembelajaran dilakukan secara daring selama pandemi Covid-19. Menurut Kementerian Pendidikan dan Kebudayaan Republik Indonesia, penguatan pendidikan karakter adalah penguatan karakter siswa berupa hati, rasa, pikir, dan olah raga melalui proses atau aktivitas pembelajaran yang dilakukan di satuan pendidikan yang melibatkan komponen sekolah, keluarga, dan masyarakat. Pendidikan karakter bertujuan untuk membentuk mental siswa secara psikologis maupun secara fisik. Meskipun belajar daring, guru selalu menekankan kepada siswa terkait makna dan pentingnya nilai sikap semasa sekolah maupun di masa yang akan datang ketika sudah bekerja.

Hasil penelitian secara kuantitatif berdasarkan pengalaman dan refleksi siswa terhadap pembelajaran daring selama satu tahun dilakukan dengan melakukan analisis kuesioner yang dibagikan kepada populasi sebanyak 30 siswa kelas XINKN1 SMKN 4 
Pangkalpinang. Terdapat lima pengamatan utama terkait Google Classroom dalam pembelajaran daring yang kemudian ditampilkan hasilnya secara grafis, yaitu keberadaan (Gambar 1), pemakaian (Gambar 2), kemampuan menggunakan (Gambar 3), kenyamanan (Gambar 4), dan efektivitas penggunaan (Gambar 5).

Sebanyak dua pertanyaan diberikan untuk menggali pengalaman di awal pandemi (Maret 2020) dan dua pertanyaan refleksi diberikan untuk mendapatkan kesan terhadap setahun lebih terhadap pembelajaran daring (Juli 2021) menggunakan Google Classroom. Pertanyaan pada Maret 2020 lebih kepada belum tahu atau tahu (grafik dengan batang ke-1 dan ke-2), sedangkan pertanyaan pada Juli 2021 lebih kepada tahun atau sangat tahu (grafik dengan batang ke-3 dan ke-4). Oleh karenanya analisis difokuskan pada jawaban pertanyaan ke-1 (belum tahu) dan lompatan yang didapatkan menjadi jawaban pada pertanyaan ke-4 (sangat tahu).

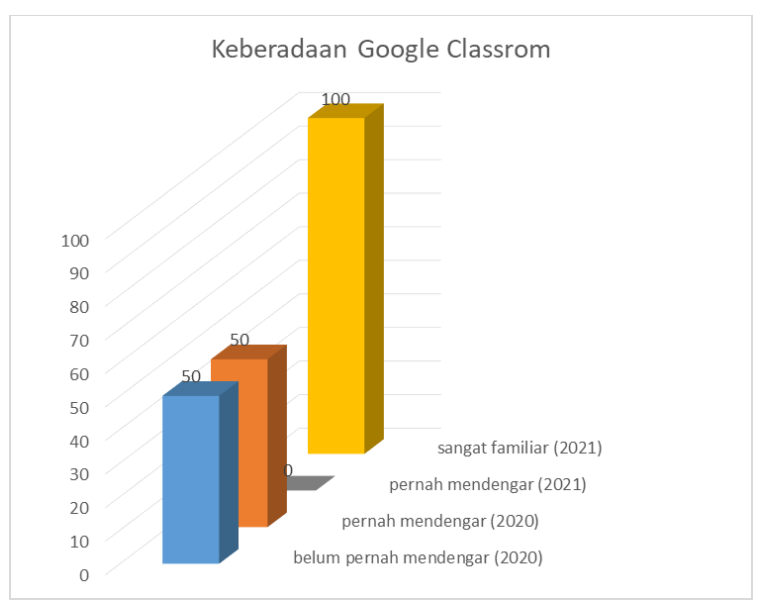

Gambar 1. Keberadaan Google Classroom
Pemakaian Google Classrom

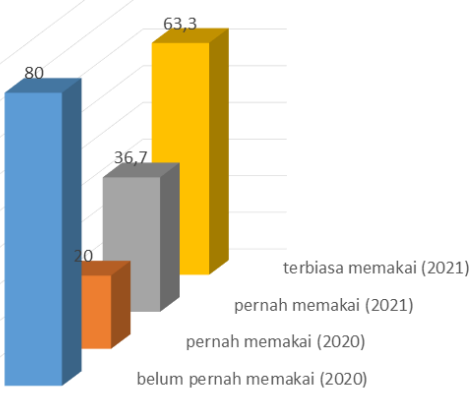

Gambar 2. Pemakaian Google Classroom

Pada Gambar 1, terjadi lompatan bahwa dulu (Maret 2020) terdapat 50\% yang belum pernah mendengar Google Classroom, sedangkan sekarang (Juli 2021) $100 \%$ menyatakan sangat familiar dengan Gogle Classroom. Dengan demikian, pandemi telah memberikan penetrasi $100 \%$ kepada siswa dari yang dulu masih ada $50 \%$ yang belum pernah mendengar Google Classroom tetapi kini tidak sekedar mendengar tapi sangat familiar.

Pada Gambar 2, terjadi lompatan bahwa dulu (Maret 2020) terdapat $80 \%$ yang belum pernah memakai Google Classroom, sedangkan sekarang (Juli 2021) 63,3\% menyatakan telah terbiasa memakai Gogle Classroom.

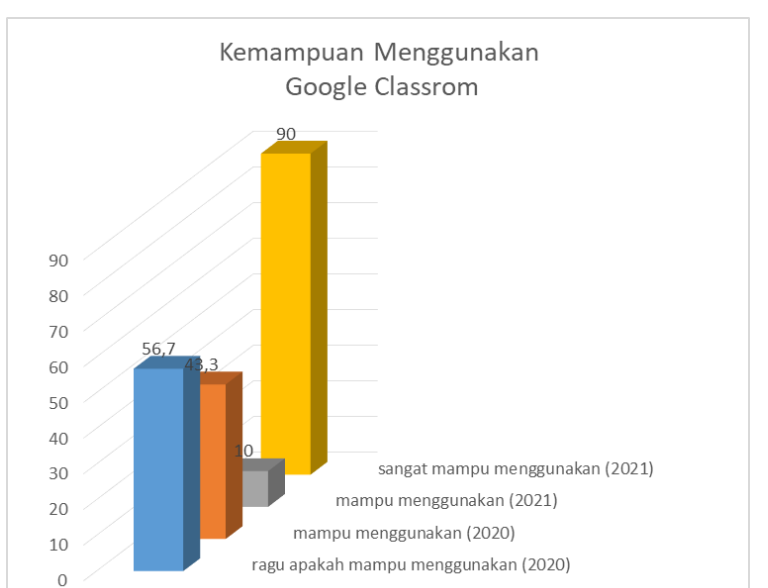

Gambar 3. Kemampuan Menggunakan Google Classroom 
Kenyamanan Penggunaan Google Classrom

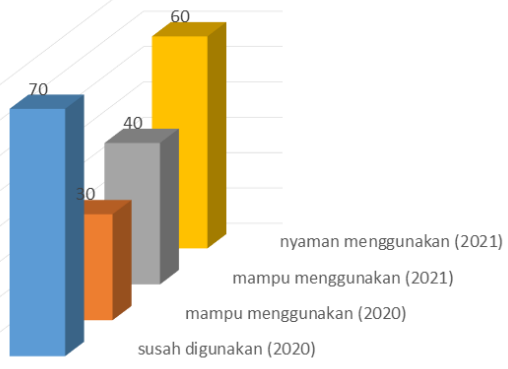

Gambar 4.Kenyamanan Penggunaan Google Classroom

Pada Gambar 3, terjadi lompatan bahwa dulu (Maret 2020) terdapat 56,7\% yang merasa ragu apakah mampu menggunakan Google Classroom, sedangkan sekarang (Juli 2021) $90 \%$ menyatakan sangat mampu menggunakan Gogle Classroom sementara hanya $10 \%$ yang merasa mampu atau tidak berani menyatakan sangat mampu. Pada Gambar 4, terjadi lompatan bahwa dulu (Maret 2020) terdapat 70\% yang berfikir susah menggunakan Google Classroom, sedangkan sekarang (Juli 2021) 60\% menyatakan merasa nyaman menggunakan Google Classroom.

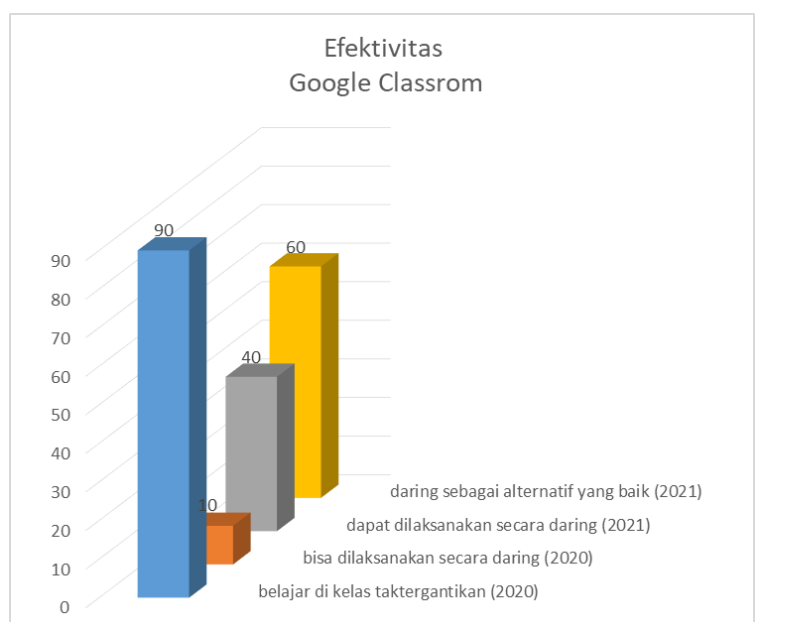

Gambar 5. Efektivitas Google Classroom

Pada Gambar 5, terjadi lompatan bahwa dulu (Maret 2020) terdapat 90\% yang menyatakan pembelajaran tatap muka di kelas tidak akan dapat tergantikan, sedangkan sekarang (Juli 2021) 60\% menyatakan Google Classroom sebagai alternatif media pembelajaran yang baik yang dapat digunakan untuk pembelajaran.

Kelebihan yang dimiliki oleh Google Classroom menurut Appas (2015) yang juga dialami penulis selama mendampingi pembelajaran diantaranya adalah manajemen akun harus memakai akun Gmail Apps for Education, terbatasnya pilihan integrasi dengan Google Calendar sehingga sulit mengorganisir materi dan deadline, kesulitan dengan simbol-simbol Google, file Word harus dikonversi ke Google Doc terlebih dahulu, tidak ada update otomatis mengenai tugas, sulitnya pembelajar berbagi tugas kepada teman lain, pembelajar dapat mengubah soal yang telah diberikan, tidak ada kuis atau tes otomatis, dan belum tersedianya chat live. Sedangkan kelebihan Google Classroom diantaranya adalah mudah digunakan melalui komputer, mobile phones ataupun tablet, efektif dalam berkomunikasi dan menyalurkan berbagai materi ataupun informasi, menghemat waktu dalam pengumpulan tugas, meningkatkan kerja sama dan komunikasi, tidak memerlukan kertas, ramah, aman, dan sistem komen yang menarik.

\section{Simpulan}

Proses pembelajaran daring (online) menggunakan aplikasi Google Classroom merupakan hal yang baru bagi guru maupun bagi siswa di SMK Negeri 4 Pangkalpinang yang dalam praktek penggunaannya masih menemui hambatan-hambatan dari segi aplikasi maupun dari segi penggunaannya. Meskipun aplikasi Google Classroom ini hanya digunakan selama masa darurat pandemi Covid-19 tetapi guru dan siswa mampu mengunakannya secara efektif terutama dalam proses pembelajaran.

Kelebihan dan kekurangan berdasarkan pengalaman penulis dalam mengawal pembelajaran daring dari awal pandemi (Maret 2020) hingga sekarang (Juli 2021) secara kualitatif telah mendapatkan efektivitas pembelajaran daring. Google Classroom telah 
menjadi pengganti pertemuan di kelas secara luring, dengan segala kelebihan dan kekurangannya. Secara kuantitatif yang dirasakan oleh siswa telah mendapatkan respon positif dengan penetrasi dan lompatan dalam lima hal, yaitu keberadaan, pemakaian, kemampuan menggunakan, kenyamanan, dan efektivitas penggunaan Google Classroom seperti yang telah diuraikan pada bagian hasil dan pembahasan.

Walaupun pihak sekolah telah memberikan keleluasaan kepada guru untuk menggunakan aplikasi yang dapat memudahkan siswa mengaksesnya, tetapi tetap saja guru dapat memilih yang terbaik untuk tercapainya tujuan pembelajaran yang telah ditetapkan. Pihak sekolah terutama guru selalu mempertimbangkan penggunaan aplikasi Google Classroom secara berkelanjutan terutama terkait dengan keadaan ekonomi dan sosial siswa agar tidak membebani siswa dan orang tua siswa, meskipun aplikasi ini merupakan salah satu aplikasi yang efektif di masa pandemi Covid-19.

\section{Daftar Pustaka}

[1] Aji, Rizqon Halal Syah (2020). Dampak Covid-19 pada Pendidikan di Indonesia: Sekolah, Keterampilan, dan Proses Pembelajaran. Salam Jurnal Sosial Budaya Syar'l, 7(5), 395-402.

[2] Baharuddin \& Rabial Kanada (2017). Pengembangan Profesionalisme Guru melalui In House Training. Journal of Islamic Education Management, 3(2), 1-20.

[3] Cahyati, Nika dan Rita Kusumah (2020). Peran Orang Tua dalam Menerapkan Pembelajaran di Rumah saat Pandemi Covid 19. Jurnal Golden Age: Universitas Hamzanwadi, 4(1), 152159.

[4] Firdaus, Muhammad Dzaky (2018). Pengembangan Aplikasi Pesan Instan WhathsApp dalam Pembelajaran
Microteaching Sebagai Media Alat Bantu Belajar Mandiri Mahasiswa Pendidikan Teknik Otomotif Universitas Negeri Yogyakarta. (Skripsi, tidak dipublikasikan). Universitas Negeri Yogyakarta, Yogyakarta.

[5] Hanafi, Muhammad (2017). Membangun Profesionalisme Guru dalam Bingkai Karakter. Jurnal IImu Budaya, 5(1).

[6] Jayadipura, Yadi (2018). In House Training untuk Meningkatkan kemampuan Guru dalam Menyusun RPP. Jurnal Idaarah, II(2), 260-268.

[7] Makarina, Muh. Murtaqi (2019, Agustus 16). Pemanfaatan Aplikasi Daring Media Sosial WhatsApp Sebagai Media Pembelajaran Bahasa Arab Berbasis ICT (Information and Communication Tecnologies). Academia Edu. https://www.academia.edu/40778589 /Pemanfaatan_Aplikasi_Daring_Media _Sosial_WhatsApp_sebagai_Media_Pe mbelajaran_Bahasa_Arab_Berbasis_IC T_Information_and_Communication_T echnologies

[8] Muhlison (2014). Guru Profesional: Sebuah Karakteristik Guru Ideal dalam Pedidikan Islam. Jurnal Darul IImi, 2(2).

[9] Mulyani, Elisabeth Wiwik Sri (2018). Dampak Pemanfaatan Android dalam Pembelajaran Banguan Ruang. Jurnal Teknologi Pendidikan, 6(2), 122-136.

[10] Muthmainnah, S., Riche, Cepi (2019). Hubungan antara Pembelajaran Menggunakan Kelas Maya dengan Kemandirian Belajar Mahasiswa. Edutcehnologia.3.3(1).

[11] Ngafifi, Muhamad (2014). Kemajuan Teknologi dan Pola Hidup Manusia dalam Perspektif Sosial Budaya. Jurnal Pembangunan Pendidikan: Fondasi dan Aplikasi 2(1). 
[12] Peraturan Pemerintah Republik Indonesia Nomor 32 Tahun 2013 tentang Perubahan atas Peraturan Pemerintah Nomor 19 Tahun 2005 tentang Standar Nasional Pendidikan.

[13] Pratiwi, Ericha Windhiyana (2020). Dampak Covid-19 Terhadap Kegiatan Pembelajaran Online di Sebuah Perguruan tinggi Kristen di Indonesia. Perspektif Ilmu Pendidikan, 34(1).

[14] Rasyid, Muhammad Rusydi (2008). Optimalisasi Peran Guru dalam Proses Transformasi Pengetahuan dengan Menggunakan Media Pembelajaran. Lentera Pendidikan, II(2), 55-68.

[15] Sahidillah, Muhammad Wildan dan Prarasto Miftahurrisqi, (2019). WhatsApp Sebagai Media Literasi Digital Siswa. Jurnal Varia Pendidikan, 6(1), 52-57.

[16] Sartika. Kegunaan WhatsApp sebagai Media Informasi dan Media Pembelajaran Informasi dan Media Pembelajaran pada Mahasiswa Ilmu Komunikasi STSIP Persada Bunda. Jurnal Medium, 6(2).

[17] Surat Keputusan Menteri No. 04 Tahun 2020. Pelaksanaan Kebijakan Pendidikan dalam Masa Darurat Penyebaran Corona Virus Disease (Covid-19) .

[18] Undang-Undang Republik Indonesia Nomor 14 Tahun 2005 tentang Guru dan Dosen
[19] Verma, Anuradha dan Anoop Singh, (2010). Webinar: Education Through Digital Collaboration. Jurnal of Emerging Technologies in Web Intelligence, 2(2), 131-136.

[20] Wardani (2012). Mengembangkan Profesionalisme Pendidik Guru: Kajian Konseptual dan Operasional. Jurnal Pendidikan, 13(1), 32-44.

[21] Winingsih, Endang (2020). Peran Orang Tua dalam Pembelajaran Jarak Jauh. Diakses dari: https://poskita.co/2020/04/02/peranorangtua-dalam-pembelajaran-jarakjauh/

[22] Zhafira, N.H., Yenny E., dan Chairiyaton (2020). Persepsi Mahasiswa terhadap Perkuliahan Daring sebagai Sarana Pembelajaran Selama Masa Karantina Covid 19. Jurnal Bisnis dan Kajian Strategi Manajemen, 4.

\section{Profil Penulis}

Sarjono, S.Pd. lahir di Sragen Jawa Tengah tanggal 11 Maret 1969. Penulis menyelesaikan pendidikan sarjana pada Program Studi Kimia Fakultas Keguruan dan IImu Pendidikan Universitas Sebelas Maret Surakarta pada tahun 1997. Saat ini penulis menjadi guru Aparatur Sipil Negara yang ditempatkan di SMK Negeri 4 Pangkalpinang Provinsi Bangka Belitung. 